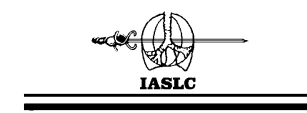

ELSEVIER

\title{
High serum YKL-40 level in patients with small cell lung cancer is related to early death
}

\author{
Julia S. Johansen ${ }^{a, b, *}$, Lars Drivsholm ${ }^{c}$, Paul A. Price ${ }^{d}$, \\ Ib Jarle Christensen e,f
}

${ }^{a}$ Department of Medicine, Division of Rheumatology Q Herlev Hospital, Herlev Ringvej 75, Herlev DK-2730, Denmark

bepartment of Medicine, Division of Rheumatology, Hvidovre Hospital, University of Copenhagen, Denmark

c Department of Oncology, Næstved Hospital, Denmark

d Department of Biology, University of California San Diego, La Jolla, CA, USA

e Finsen Laboratory, H:S Rigshospitalet, Department of Surgical Gastroenterology,

Hvidovre Hospital, University of Copenhagen, Denmark

f Department of Surgical Gastroenterology, Hvidovre Hospital, University of Copenhagen, Denmark

Received 24 February 2004; received in revised form 3 May 2004; accepted 6 May 2004

\section{KEYWORDS}

Small cell lung

carcinoma;

Tumor invasiveness;

YKL-40;

HC gp-39

\begin{abstract}
Summary YKL-40, a growth factor for connective tissue cells, is secreted by cancer cells and macrophages. Elevated serum YKL-40 in patients with metastatic carcinoma has been associated with poor prognosis. We evaluated serum YKL-40 in 131 patients with small cell lung cancer (SCLC). Twenty-two percent of the patients with limited disease and $40 \%$ of the patients with extensive disease had elevated serum YKL-40. The median survival was 5.1 months for patients with elevated serum YKL-40 and 9.0 months for patients with normal serum YKL-40. Patients with elevated serum YKL-40 had increased hazard for death within the first 6 months after the start of chemotherapy compared to patients with normal serum YKL-40 ( $\mathrm{HR}=2.06, P=0.009)$. Multivariate Cox analysis including routine prognostic variables showed that serum YKL-40 $(P=0.02)$ is independent of prognostic variables for survival within the first 6 months. Studies are needed to determine the function of YKL-40 in SCLC.

(c) 2004 Elsevier Ireland Ltd. All rights reserved.
\end{abstract}

\section{Introduction}

YKL-40, a member of the mammalian family 18 glycosyl hydrolases [1-3], is secreted in large amounts in vitro by the MG63 human osteosarcoma cell line

\footnotetext{
"Corresponding author. Tel.: +45 44884243; fax: +45 44884214 .

E-mail address: julia.johansen@post3.tele.dk (J.S. Johansen).
}

[4] and expressed selectively by murine mammary tumors initiated by neu/ras oncogenes [2]. A search of the YKL-40 protein sequence against the dbest database at the National Center for Biotechnology Information has shown that YKL-40 is expressed by several types of carcinoma (breast, colon, lung, kidney, ovarian, prostate, uterine, osteosarcoma, oligodendroglioma, glioblastoma and germ cell tumors). Gene expression microarray analyses have shown that YKL-40 is one of the most differentially 
expressed gene in papillary thyroid carcinoma [5], glioblastoma multiforme [6], and extracellular myxoid chondrosarcoma [7].

The gene for YKL-40 is known [8,9] and located on chromosome 1q31-q32. The crystallographic three-dimensional structure of human $[10,11]$ and goat YKL-40 [12] are described but the site and mode of binding to cell surface receptors is not yet known. YKL-40 is a heparin and chitin-binding lectin $[3,13]$ without chitinase activity $[1,13]$. The biological function of $\mathrm{YKL}-40$ in cancer diseases is not known, but YKL-40 is a growth factor for connective tissue cells $[14,15]$ and a potent migration factor for endothelial cells [16] and vascular smooth muscle cells [17].

Serum levels of YKL-40 in patients with glioma are related with tumor grade and burden [6]. Increased serum YKL-40 levels are found in patients with primary and metastatic breast carcinoma [18-20] and ovarian carcinoma [21,22], and in preand post-operative samples from patients with colorectal carcinoma $[23,24]$. It was found in these studies that high serum YKL-40 levels were related to short recurrence-free interval and poor survival of the patients.

The aim of the present study was to evaluate the value of pretreatment serum levels of YKL-40 in patients with small cell lung cancer (SCLC) at the time of diagnosis in relation to disease stage and survival.

\section{Patients and methods}

\subsection{Patients}

One hundred and thirty one consecutive patients ( 82 males and 49 females; median age of 57 years, range 37-79 years) with SCLC from four different hospitals were included in the study. The patients participated in the "Copenhagen Lung Cancer Study Group" [25]. At the time of diagnosis and before chemotherapy, blood samples were collected from all patients. Exclusion criteria was prior cancer. The patients were included between April 1989 and January 1991 and followed until death or at least 64 months for censored observations (range 64-92). One hundred and twenty seven of the 131 patients died during the study period. Time to death was measured from the date of starting chemotherapy. There were 24 early deaths (i.e. within the first 30 days), progressive $\mathrm{SCLC}=12$, toxic death $=5$, cardiovascular $=3$ and "unknown" $=4$.

At inclusion, all patients had a medical history, clinical examination, a full blood count and a biochemical screen of renal and liver function, a chest X-ray, and ultrasonic verification of suspected supra-diaphragmatic lymph nodes. Lung cancer was confirmed by plain chest X-ray in doubtful cases supported by a computer tomographic (CT) evaluation. SCLC was confirmed cytologically or histologically. Malignancy in a pleural effusion was confirmed by the demonstration of malignant cells. Abnormal biochemistry indicating liver involvement leads to ultrasonic examination of the liver with biopsy. All patients had a bone marrow aspiration for verification of malignant involvement. Before treatment, the patients were classified as having limited or extensive SCLC, based on the basis of clinical examination, chest X-ray, bone-marrow aspiration and biopsy from the iliac crest, and ultrasound of the liver with biopsy, if possible, of suspected regions. Limited disease was defined as disease confined to one hemithorax excluding proven malignant pleural effusion and chest wall metastases. Ipsilateral supraclavicular lymph nodes were included in the criteria of limited disease. At the time of patients enrolment in this study, staging methods were different from today. However, the international staging procedures were followed and CT was not obligatory. The simple staging of limited disease or extensive disease was "state-of-art" and no one considered TNM or "very limited disease" classification as surgery was not a treatment option. Performance status was scored according to the WHO system. Patients were treated according to treatment protocols, including combinations of platin analogues, podophyllotoxin derivatives, alkylating agents and vinca alkaloids [25]. None of the patients were treated with surgery or radiotherapy. The study was performed in agreement with the Helsinki II declaration. The research protocol was approved by the central ethical committee. The patients were informed about the possibility of withdrawing from the study at any time. Further details about some of the patients are described elsewhere [26].

\subsection{Healthy controls}

The normal range of serum YKL-40 was determined in 260 adults ( 116 males and 144 females, median age of 48 years, range 18-79 years). They were all healthy, were not on any medication, and had no clinical signs or symptoms of cancer, joint, liver, kidney, metabolic or hormonal disease [27].

\subsection{Biochemical analysis}

Blood samples from the patients were taken before the start of chemotherapy. Serum was separated from cellular elements by centrifugation within two 
hours after blood sampling. All serum samples were stored at $-80^{\circ} \mathrm{C}$ until analysis. Serum YKL-40 was determined by an in-house RIA [28] using rabbit antibody raised against human YKL-40. The sensitivity of the RIA is $20 \mu \mathrm{g} / \mathrm{l}$. The intra-assay and inter-assay coefficient of variation are $<6.5 \%$ and $<12.0 \%$, respectively. YKL- 40 is stable at $-80^{\circ} \mathrm{C}$ for at least 10 years (personal observation) and the measurement of the serum YKL- 40 concentrations in the patients was performed in 1996. Smoking has no effect on serum YKL-40 levels (personal observation). Serum LDH was measured by routine method. The serum LDH level was not determined in 10 patients.

\subsection{Statistical analysis}

The SAS ${ }^{\circledR}$ software package (version 8.2; SAS Institute, Cary, NC) was used to manage the patient data and to perform all statistical analyses. A normal reference region was calculated as described by Royston [29] on the log-transformed serum YKL-40 values of the healthy controls adjusting for age, and the $95 \%$ percentile was chosen as the upper limit. The serum YKL-40 levels in the patients were scored as normal or elevated (by the normal age adjusted serum YKL-40 level as described above). The end-point for survival analysis was death of all causes as well as cancer-related death with survival time measured from the day chemotherapy was initiated. The Kaplan-Meier method was used to estimate survival probabilities, and the log rank test was used to test for equality of strata. The Cox proportional hazards model was used for the analysis of continuous covariates as well as for multivariate analysis including time dependent covariates. The assumption of proportional hazards was verified graphically where applicable. Rank statistics were used to calculate correlation coefficients and to test hypothesis on location. Tests of independence were done using the chi square-test. The significance level was set to $5 \%$.

\section{Results}

The median serum YKL-40 concentration in the patients with SCLC was $172 \mu \mathrm{g} / \mathrm{l}$ (range 48-2481 $\mu \mathrm{g} / \mathrm{l}$ ) and significantly elevated $(P<0.001)$ compared with the level in the healthy age-matched controls (median $102 \mu \mathrm{g} / \mathrm{l}$, range 38-514 $\mu \mathrm{g} / \mathrm{l}$ ). Thirty-three percent of the patients had serum YKL-40 above the 95th percentile (age-corrected) of the healthy controls. A weak but significant correlation was found between serum YKL-40 and age in the patients (Spearmans $\rho=0.23, P=0.008$ ). No correlation was found between serum YKL-40 and serum LDH (Spearmans $\rho=0.08, P=0.40$ ).

Table 1 shows the associations between serum YKL-40 and LDH levels and age, performance status and disease extension. Patients with extended disease $(n=72)$ had significantly higher serum YKL-40 $(P=0.004$, Wilcoxon rank sum test) compared to

Table 1 Relation between serum YKL-40 and LDH levels and clinical/biochemical parameters in patients with small cell lung cancer

\begin{tabular}{|c|c|c|c|c|c|c|}
\hline & \multirow[t]{2}{*}{$n$} & \multicolumn{2}{|c|}{ Serum YKL-40 ( $\mu \mathrm{g} / \mathrm{l})$} & \multirow[t]{2}{*}{$n^{\mathrm{a}}$} & \multicolumn{2}{|l|}{ Serum LDH (U/l) } \\
\hline & & Median (range) & $P$-value & & Median (range) & $P$-value \\
\hline \multicolumn{7}{|l|}{ Gender } \\
\hline Male & 82 & $186(48-2481)$ & 0.32 & 76 & $489(144-6050)$ & 0.93 \\
\hline Female & 49 & $147(60-2047)$ & & 45 & $441(270-5540)$ & \\
\hline \multicolumn{7}{|l|}{ Age (years) } \\
\hline$<70$ & 109 & $167(48-2481)$ & 0.16 & 100 & $482(221-6050)$ & 0.19 \\
\hline$\geq 70$ & 22 & $218(56-2047)$ & & 21 & $422(144-4522)$ & \\
\hline \multicolumn{7}{|c|}{ Performance status } \\
\hline$\leq 1$ & 90 & $172(48-2481)$ & 0.89 & 83 & $441(144-5540)$ & 0.62 \\
\hline$>1$ & 41 & $160(64-2047)$ & & 38 & $574(227-6050)$ & \\
\hline \multicolumn{7}{|c|}{ Disease stage } \\
\hline Limited & 59 & $149(48-870)$ & 0.004 & 55 & $149(48-870)$ & 0.0001 \\
\hline Extended & 72 & $210(56-2481)$ & & 66 & $664(270-6050)$ & \\
\hline \multicolumn{7}{|c|}{ Serum LDH (U/l) } \\
\hline$\leq 450$ & 57 & $167(64-884)$ & 0.77 & & & \\
\hline$>450$ & 64 & $175(48-2481)$ & & & & \\
\hline
\end{tabular}

a The serum LDH level was not determined in 10 patients. 
Table 2 Univariate and multivariate analysis of overall survival after diagnosis of SCLC

\begin{tabular}{|c|c|c|c|c|c|c|}
\hline \multirow[t]{2}{*}{ Covariate } & \multicolumn{3}{|c|}{ Univariate Cox analysis } & \multicolumn{3}{|c|}{ Multivariate Cox analysis } \\
\hline & HR & $(95 \% \mathrm{Cl})$ & $P$-value & HR & $(95 \% \mathrm{Cl})$ & $P$-value \\
\hline Sex: female vs. male & 0.73 & $0.51-1.05$ & 0.09 & 0.73 & $0.51-1.05$ & 0.09 \\
\hline Age: age $<70$ years vs. age $\geq 70$ years & 1.76 & $1.10-2.81$ & 0.02 & 1.92 & $1.20-3.09$ & 0.007 \\
\hline Disease stage: limited vs. extensive & 1.75 & $1.23-2.50$ & 0.002 & 1.51 & $1.04-2.18$ & 0.03 \\
\hline Performance status: $0-1$ vs. $2-4$ & 2.57 & $1.72-3.83$ & $<0.0001$ & 2.60 & $1.69-4.00$ & $<0.0001$ \\
\hline Serum LDH: $\leq 450 \mathrm{U} / \mathrm{l}$ vs. $>450 \mathrm{U} / \mathrm{l}$ & 1.70 & $1.17-2.46$ & 0.005 & 1.47 & $0.98-2.21$ & $0.06^{\mathrm{b}}$ \\
\hline Serum YKL- $4 \overline{0}^{\mathrm{a}}$ level: high vs. normal & 1.33 & $0.91-1.95$ & 0.14 & 1.28 & $0.86-1.89$ & 0.22 \\
\hline
\end{tabular}

$\mathrm{HR}$, relative hazard ratio; $\mathrm{Cl}$, confidence interval.

${ }^{\text {a }}$ Cut-off is the age-corrected $95 \%$ percentile of healthy adults.

${ }^{\mathrm{b}}$ Adjusted for 10 missing values.

patients with limited disease $(n=59)$, and both patient groups had elevated serum YKL-40 compared to controls (limited: $P=0.019$; extended: $P<0.001$, Wilcoxon rank sum test). Twenty-two percent of the patients with limited disease had elevated serum YKL-40 (i.e. higher than the 95th percentile of the age-corrected healthy controls) and $40 \%$ of the patients with extensive disease had elevated serum YKL-40. There was no difference in serum YKL-40 between the age-group $(<70$ years versus $\geq 70$ years), gender, performance status $(\leq 1$ versus $>1)$, and serum LDH $(\leq 450 \mathrm{U} / \mathrm{l}$ versus $>450 \mathrm{U} / \mathrm{l}$ ). Serum LDH was also significantly elevated in the patients with extended disease compared to patients with limited disease $(P<0.0001$, Wilcoxon rank sum test).

\subsection{Serum YKL-40 in relation to survival}

The median survival time was 7.7 months. Four patients were long-term survivors (i.e. survived for more than 5 years). The median survival time for the patients with elevated serum YKL-40 was 5.1 months compared to 9.0 months for the patients with normal serum YKL-40. Thirty-six percent $(15 / 42)$ of the patients with elevated serum YKL-40 died within 1 month compared to only $10 \%(9 / 89)$ of the patients with normal serum YKL-40 $(P=0.0004$, chi-square test). The Kaplan-Meier estimates of survival stratified by serum YKL-40 are shown in Fig. 1. High serum YKL-40 did not predict shorter survival after start of chemotherapy compared to patients with normal serum YKL-40 ( $P=0.14$, log rank test). Visual inspection of the Kaplan-Meier curves suggests an increased number of early deaths in the group with elevated YKL-40, and testing the null hypothesis by Wilcoxon test suggests a significant difference $(P=0.003)$ attributable to the early deaths.
The median survival time for the patients with elevated serum LDH was 5.5 months compared to 10.4 months for the patients with normal serum LDH (i.e. $\leq 450 \mathrm{U} / \mathrm{l}$ ). Nineteen percent $(12 / 64)$ of the patients with elevated serum LDH were dead within 1 month compared to $18 \%(10 / 57)$ of the patients with normal serum LDH ( $P=0.86$, chi-square test). High serum LDH predicted shorter survival compared to patients with normal serum $\operatorname{LDH}(P=0.006$, log rank test).

Univariate Cox regression analysis showed that SCLC patients with high serum YKL-40 at the time of diagnosis did not have a higher hazard for death within the following 24 months $(\mathrm{HR}=1.33,95 \% \mathrm{Cl}$ : 0.91-1.95, $P=0.14$ ) compared to patients with normal serum YKL-40 (Table 2, left). Univariate Cox regression analysis also showed that SCLC patients with high serum LDH, patients older than 70 years, patients with extensive disease and high performance status were predictors of poor prognosis (Table 2, left). Multivariate Cox regression analysis showed that age, disease stage and performance status were independent prognostic variables of survival (Table 2 , right).

Thirty-eight (53\%) of the patients with extended disease and $15(25 \%)$ of the patients with local disease died within 6 months after starting chemotherapy. Univariate Cox regression analysis with serum YKL-40 levels as a time dependent covariate demonstrated that patients with an elevated serum YKL-40 had a high hazard ratio for death within the first 6 months (HR $=2.06,95 \% \mathrm{Cl}: 1.19-3.54, P=0.009$ ). Multivariate Cox regression analysis of survival of patients with SCLC within the first 6 months after starting chemotherapy showed that high serum YKL-40 was an independent prognostic variable of short survival (Table 3). Censoring 12 patients dying within the first month of treatment related or unknown causes showed that high serum YKL-40 suggested early cancer specific death (Wilcoxon test, $P$ 


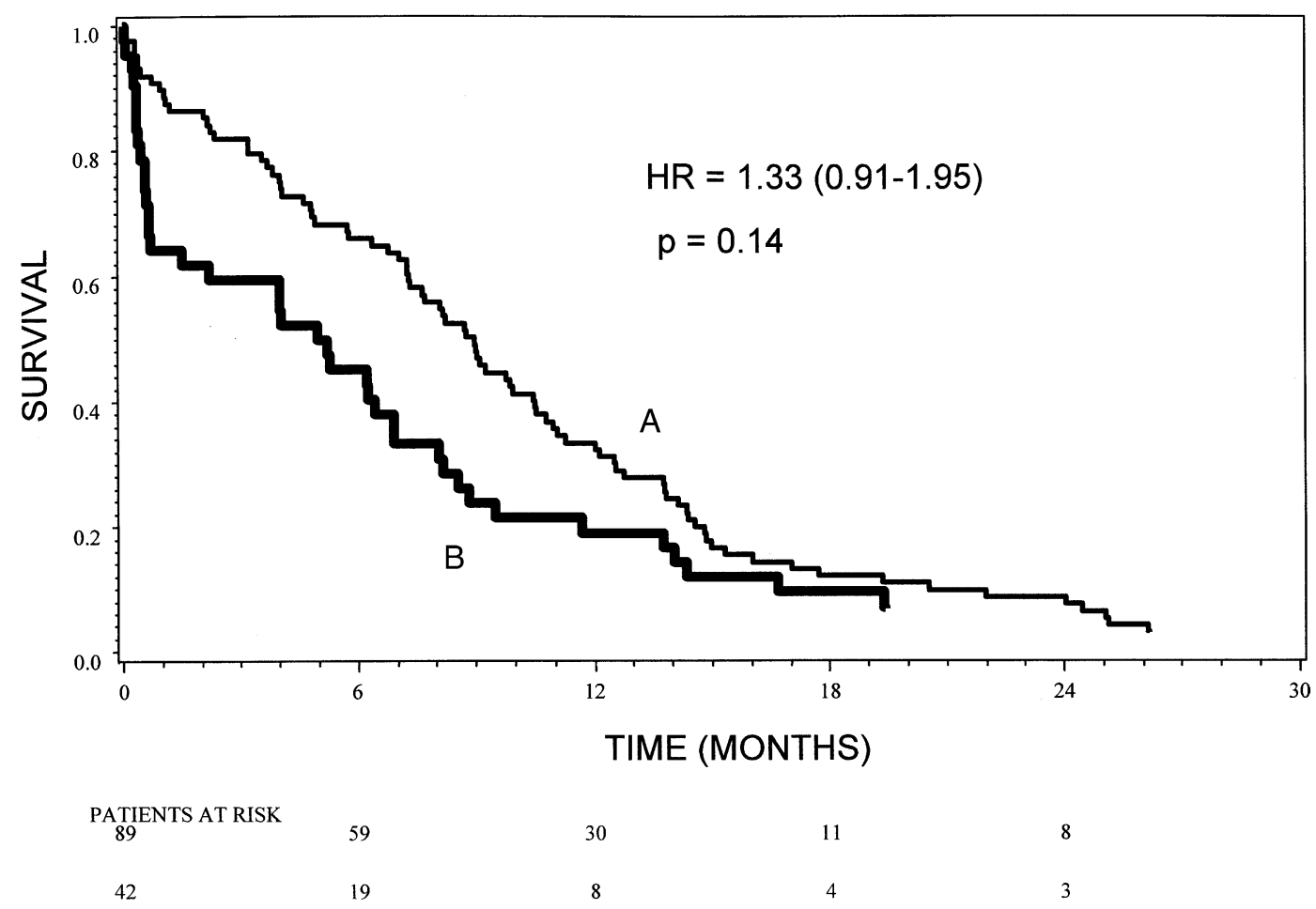

Fig. 1 Survival curves showing the association between serum YKL-40 and overall survival in SCLC patients. Patients are dichotomized according to elevated vs. normal serum YKL-40 level at diagnosis of SCLC and before chemotherapy. The strata are patients having normal serum YKL-40 $(n=89)$. The cut-off limit is the age-corrected $95 \%$ percentile of serum YKL-40 in healthy adults. The $P$-value shown is for the log rank test for equality of strata. The number of deaths is shown for stratum $A$ and the number of patients at risk in the stratum is shown for $0,6,12,18$ and 24 months.

$=0.03)$ in the time-dependent univariate model $(P$ $=0.07$ ) as well as in a multivariate model including all covariates shown in Table $3(\mathrm{HR}=1.76,95 \% \mathrm{Cl}$ : 0.93-3.34, $P=0.08$ ).

\section{Discussion}

This is the first report on serum concentration of YKL-40 in patients with SCLC at the time of diagnosis. We found elevated serum YKL-40 in $22 \%$ of the patients with limited disease and in $40 \%$ of the patients with extensive disease. There was no relationship between serum YKL-40 levels and LDH and performance status of the patients. The percentage of patients with extensive SCLC with elevated serum YKL-40 is comparable to the percentage of patients with metastatic breast, colorectal and ovarian carcinoma with elevated serum YKL-40 [19-24]. The present study also showed that an elevated serum YKL-40 level at time of diagnosis reflected increased lung cancer aggressiveness since patients with high serum YKL-40 had shorter
Table 3 Multivariate analysis of overall survival after diagnosis of SCLC with YKL-40 as a time dependent covariate stratified by high or normal level

\begin{tabular}{lllc}
\hline Covariate & \multicolumn{3}{l}{ Multivariate Cox analysis } \\
\cline { 2 - 4 } & $\mathrm{HR}$ & $(95 \% \mathrm{Cl})$ & $P$-value \\
\hline $\begin{array}{c}\text { Sex: female vs. male } \\
\text { Age: age }<70 \text { years } \\
\quad \text { vs. age } \geq 70 \text { years }\end{array}$ & 0.74 & $0.51-1.06$ & 0.10 \\
$\begin{array}{c}\text { Disease stage: limited } \\
\text { vs. extensive }\end{array}$ & 1.50 & $1.04-2.17$ & 0.03 \\
$\begin{array}{c}\text { Performance status: } \\
\quad 0-1 \text { vs. } 2-4\end{array}$ & 2.60 & $1.72-3.93$ & $<0.0001$ \\
$\begin{array}{c}\text { Serum LDH: } \leq 450 \mathrm{U} / \mathrm{l} \\
\quad \text { vs. }>450 \mathrm{U} / \mathrm{l}\end{array}$ & 1.45 & $0.97-2.17$ & $0.07^{\mathrm{b}}$ \\
$\begin{array}{c}\text { Serum YKL-40 level: } \\
\text { high vs. normal }\end{array}$ & 1.96 & $1.13-3.40$ & 0.02 \\
\hline
\end{tabular}

$\mathrm{HR}$, relative hazard ratio; $\mathrm{Cl}$, confidence interval.

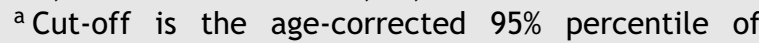
healthy adults.

${ }^{\mathrm{b}}$ Adjusted for 10 missing values. 
survival within the first 6 months than patients with normal serum YKL-40. Furthermore, multivariate Cox analysis including the classical parameters with known prognostic value in patients with SCLC showed that the serum YKL-40 level did give additional information of survival within the first 6 months after the start of chemotherapy. These results are in accordance with studies of patients with metastatic breast, colorectal, and ovarian carcinoma where high serum YKL-40 predicted shorter time to progression and shorter survival compared to patients with normal serum YKL-40 [19-24]. It has also been shown that serum YKL-40 was independent of serum CEA in colorectal cancer patients $[23,24]$, of estrogen receptor status and HER2 status in breast cancer patients [20], and of serum CA125 in ovarian cancer patients $[21,22]$. Cintin et al. [24] found that during the follow-up of curatively operated colorectal cancer patients a high post-operative serum YKL-40 level was an independent predictor of death within the following 6 months [24]. These results suggest that determination of serum YKL-40 may be useful as a "prognosticator" in patients with cancer, including SCLC. It may be of clinical value to identify SCLC patients with a very poor prognosis (i.e. survival $<6$ months). Patients with very poor prognosis could be offered special treatments with, e.g. few side-effects in order to obtain maximum quality of life in "terminal life" or new alternative treatments.

Our result of the prognostic value of serum LDH levels is in accordance with the literature showing that an elevated serum LDH is a prognostic parameter of short survival in patients with SCLC [30-33]. When serum LDH was included in the multivariate analysis it was not an independent prognostic variable. The present study also suggests that high serum YKL-40 predicts death within 6 months in SCLC patients independent of the serum LDH level and the effect is diminished with time. Serum LDH predicts survival over a longer period, and a time dependence similar to serum YKL-40 could not be demonstrated.

Lung cancer is the most common cause of death from cancer in western countries and was responsible for 157,200 deaths in United States in 2003 [34] and 330,000 deaths in Europe in 1995 [35]. SCLC accounts for approximately $20-25 \%$ of these deaths. Despite new diagnostic techniques and therapy, the overall 5-year survival rates for patients with SCLC remains low at about $4 \%$. There are no routinely used serological parameter for screening of SCLC and screening studies using chest radiography or computed tomography have not shown a reduction in mortality from lung cancer [36]. The patients in- cluded in present study were treated in the period 1989 to late 1991 with standard chemotherapy regiments for treatment of SCLC. Forty percent $(53 / 131)$ of our patients were dead within 6 months and $21 \%(15 / 72)$ of the patients with extended disease died within the first month of starting chemotherapy. The anti-neoplastic treatment for SCLC has changed since this study started but we have no reason to believe that the population or the biology of the disease have changed significantly since this study started. We must of course be cautious, but we think that the results can be implemented to more modern studies of SCLC patients.

YKL-40 is not specific for SCLC. It is secreted by many different types of solid carcinomas and also by non-malignant cells in tissues characterized by inflammation, tissue degradation/remodeling or ongoing fibrogenesis. YKL-40 is produced by macrophages [8,13,37-40], neutrophils [41] and arthritic chondrocytes $[1,40]$, and has been found in the fibrotic liver [42]. Elevated serum YKL-40 levels are found in patients with non-malignant diseases such as severe active rheumatoid arthritis $[28,40,43,44]$, severe bacterial infections $[45,46]$ and liver fibrosis $[42,47]$. These diseases are not difficult to diagnose.

Unfortunately, the exact biological function of YKL-40 is unknown. We speculate that YKL-40 producing cancer cells may have a different phenotype than the non-producing cancer cells, and thereby YKL-40 may reflect differences in the biology of various cancer cells. YKL-40 exhibits growth factor activity for cell types involved in tissue remodeling processes and increases growth rate of fibroblastic cell lines derived from osteoarthritic synovium, fetal lung and adult skin. YKL-40 is effective in a concentration range similar to IGF-1 and works synergistically with IGF-1 in stimulating growth of the fibroblasts [14]. YKL-40 may also have a role in angiogenesis, since it acts as a chemoattractant for umbilical vein endothelial cells, stimulates migration of these cells at a level comparable to that achieved by basic fibroblast growth factor, and modulates their morphology by promoting the formation of branching tubules [16]. It has also been demonstrated that YKL-40 is a novel adhesion and migration factor for vascular smooth muscle cells [17].

In conclusion, we found that the serum level of YKL-40 in patients with SCLC reflected tumor extension and that patients with a high serum YKL-40 level had a poorer short-term prognosis compared to patients with normal serum YKL-40. This finding should be validated in an independent patient sample. The biological function of YKL-40 in cancer diseases is unknown, but YKL-40 may be involved 
in cancer cell proliferation and angiogenesis. Hopefully, the function of YKL-40 in cancer diseases will be elucidated in near future.

\section{Acknowledgements}

The study was supported by grants from the "Dagmar Marshalls Foundation", "Fritz, Georg and Marie Cecilie Gluds Legat", "Michaelsen Foundation", and the "Wedell-Wedellsborgs Foundation'. The expert technical assistance of Inger Aakard and Susanne Munch, Department of Rheumatology, Hvidovre Hospital is greatly appreciated.

\section{References}

[1] Hakala BE, White C, Recklies AD. Human cartilage gp-39, a major secretory product of articular chondrocytes and synovial cells, is a mammalian member of a chitinase protein family. J Biol Chem 1993;268:25803-10.

[2] Morrison BW, Leder P. neu and ras initiate murine mammary tumors that share genetic markers generally absent in c-myc and int-2-initiated tumors. Oncogene 1994;9:341726.

[3] Shackelton LM, Mann DM, Millis AJT. Identification of a 38-kDa heparin-binding glycoprotein (gp38k) in differentiating vascular smooth muscle cells as a member of a group of proteins associated with tissue remodeling. J Biol Chem 1995;270:13076-83.

[4] Johansen JS, Williamson MK, Rice JS, Price PA. Identification of proteins secreted by human osteoblastic cells in culture. J Bone Miner Res 1992;7:501-12.

[5] Huang Y, Prasad M, Lemon WJ, Hampel H, Wright FA, Kornacker $\mathrm{K}$, et al. Gene expression in papillary thyroid carcinoma reveals highly consistent profiles. Proc Natl Acad Sci USA 2001;98:15044-9.

[6] Tanwar MK, Gilbert MR, Holland EC. Gene expression microarray analysis reveals YKL-40 to be a potential serum marker for malignant character in human glioma. Cancer Res 2002;62:4364-8.

[7] Sjogren H, Meis-Kindblom JM, Orndal C, Bergh P, Ptaszynski $\mathrm{K}$, Aman $\mathrm{P}$, et al. Studies on the molecular pathogenesis of extra-skeletal myxoid chondrosarcoma-cytogenetic. Am J Pathol 2003;162:781-92.

[8] Rehli M, Krause SW, Andreesen R. Molecular characterization of the gene for human cartilage gp-39 (CHI3L1), a member of the chitinase protein family and marker for late stages of macrophage differentiation. Genomics 1997;43:221-5.

[9] Rehli M, Ammon C, Langmann S, Schwarzfischer L, Andreesen $\mathrm{R}$, et al. Transcriptional regulation of CHI3L1, a marker gene for late stages of macrophage differentiation. J Biol Chem 2003;278:44058-67.

[10] Fusetti F, Pijning T, Kalk KH, Bos E, Dijkstra BW. Crystal structure and carbohydrate binding properties of the human cartilage glycoprotein-39. J Biol Chem 2003;278:37753-60.

[11] Houston DR, Recklies AD, Krupa JC, van Aalten DMF. Structure and ligand-induced conformational change of the
39-kDa glycoprotein from human articular chondrocytes. J Biol Chem 2003;278:30206-12.

[12] Mohanty AK, Singh G, Paramasivam M, Saravanan K, Jabeen T, Sharma $S$, et al. Crystal structure of a novel regulatory $40 \mathrm{kDa}$ mammary gland protein (MGP-40) secreted during involution. J Biol Chem 2003;278:14451-60.

[13] Renkema GH, Boot GR, Au FL, Donker-Koopman WE, Strijland A, Muijsers AO, et al. Chitotriosidase, a chitinase, and the $39-\mathrm{kDa}$ human cartilage glycoprotein, a chitin-binding lectin, are homologues of family 18 glycosyl hydrolases secreted by human macrophages. Eur J Biochem 1998;251:504-9.

[14] Recklies $A D$, White $C$, Ling $H$. The chitinase 3-like protein human cartilage 39 (HC-gp39) stimulates proliferation of human connective-tissue cells and activates both extracellular signal-regulated kinase-and protein kinase B-mediated signalling pathways. Biochem J 2002;365:11926.

[15] De Ceuninck F, Gaufillier S, Bonnaud A, Sabatini M, Lesur C, Pastoureau P. YKL-40 (cartilage gp-39) induces proliferative events in cultured chondrocytes and synoviocytes and increases glycosaminoglycan synthesis in chondrocytes. Biochem Biophys Res Commun 2001;285:926-31.

[16] Malinda KM, Ponce L, Kleinman HK, Shackelton LM, Millis AJ. Gp38k, a protein synthesized by vascular smooth muscle cells, stimulates directional migration of human umbilical vein endothelial cells. Exp Cell Res 1999;250:16873.

[17] Nishikawa KC, Millis AJT. Gp38k (CHI3L1) is a novel adhesion and migration factor for vascular cells. Exp Cell Res 2003;287:79-87.

[18] Johansen JS, Christensen IJ, Riisbro R, Greenall M, Han C, Smith $\mathrm{K}$, et al. High serum YKL-40 levels in patients with primary breast cancer is related to short recurrence free interval. Breast Cancer Res Treat 2003;80:15-21.

[19] Johansen JS, Cintin C, Jørgensen M, Kamby C, Price PA. Serum YKL-40: a new potential marker of prognosis and location of metastases of patients with recurrent breast cancer. Eur J Cancer 1995;31A:1437-42.

[20] Jensen BV, Johansen JS, Price PA. High levels of serum HER-2/neu and YKL-40 independently reflect aggressiveness of metastatic breast cancer. Clin Cancer Res 2003;9:4423-34.

[21] Høgdall EVS, Johansen JS, Kjaer SK, Price PA, Christensen L, Blaakaer J, et al. High plasma YKL-40 level in patients with ovarian cancer stage III is related to shorter survival. Oncol Rep 2003;10:1535-8.

[22] Dehn H, Høgdall EVS, Johansen JS, Price PA, Jørgensen M, Engelholm SAA, et al. Plasma YKL-40, as a prognostic tumor marker in recurrent ovarian cancer. Acta Obstet Gynecol Scand 2003;82:287-93.

[23] Cintin C, Johansen JS, Christensen IJ, Price PA, Sørensen $\mathrm{S}$, Nielsen HJ. Serum YKL-40 and colorectal cancer. Br J Cancer 1999;79:1494-9.

[24] Cintin C, Johansen JS, Christensen IJ, Price PA, Sørensen $\mathrm{S}$, Nielsen HJ. High serum YKL-40 level after surgery for colorectal carcinoma is related to short survival. Cancer 2002;95:267-74.

[25] Hirsch FR, Dombernowsky P, Hansen HH. Treatment of small cell lung cancer: the Copenhagen experience. Anticancer Res 1994;14:317-20.

[26] Drivsholm L, Paloheimo LI, Østerlind K. Chromogranin A, a significant prognostic factor in small cell lung cancer. $\mathrm{Br}$ J Cancer 1999;81:667-71.

[27] Johansen JS, Hvolris J, Hansen M, Backer V, Lorenzen I, Price PA. Serum YKL-40 levels in healthy children and adults. Comparison with serum and synovial fluid levels 
of YKL-40 in patients with osteoarthritis or trauma of the knee joint. Br J Rheumatol 1996;35:553-9.

[28] Johansen JS, Jensen HS, Price PA. A new biochemical marker for joint injury. Analysis of YKL-40 in serum and synovial fluid. Br J Rheumatol 1993;32:949-55.

[29] Royston P. Constructing time-specific reference ranges. Statist Med 1991;10:675-90.

[30] Østerlind K, Andersen PK. Prognostic factors in small cell lung cancer: multivariate model based on 778 patients treated with chemotherapy with or without irradiation. Cancer Res 1986;46:4189-94.

[31] Buccheri G, Ferrigno D. Prognostic factors in lung cancer: tables and comments. Eur Respir J 1994;7:1350-64.

[32] Buccheri G, Ferrigno D. Serum biomarkers of nonneuron-endocrine origin in small-cell lung cancer: a 16-year study on carcinoembryonic antigen, tissue polypeptide antigen and lactate dehydrogenase. Lung Cancer 2000;30:37-49.

[33] Quoix E, Purohi A, Faller-Beau M, Moreau L, Oster JP, Pauli $\mathrm{G}$. Comparative prognostic value of lactate dehydrogenase and neuron-specific enolase in small-cell lung cancer patients treated with platinium-based chemotherapy. Lung Cancer 2000;30:127-34.

[34] Jemal A, Murray T, Samuels A, Ghafoor A, Ward E, Thun M. Cancer statistics, 2003. CA Cancer J Clin 2003;53:5-26.

[35] Bray F, Sankila R, Ferlay J, Parkin DM. Estimates of cancer incidence and mortality in Europe in 1995. Eur J Cancer 2002;38:99-166.

[36] Patz EF, Goodman PC, Bepler G. Screening for lung cancer. N Engl J Med 2000;343:1627-33.

[37] Boot RG, van Achterberg TAE, van Aken BE, Renkema GH, Jacobs MJHM, Aerts JMFG, et al. Strong induction of members of the chitinase family of proteins in atherosclerosis. Chitotriosidase and human cartilage gp-39 expressed in lesion macrophages. Arterioscler Thromb Vasc Biol 1999;19:687-94.

[38] Johansen JS, Baslund B, Garbarsch C, Hansen M, Stoltenberg M, Lorenzen I, et al. YKL-40 in giant cells and macrophages from patients with giant cell arteritis. Arthritis Rheum 1999;42:2624-30.
[39] Baeten D, Boots AMH, Steenbakkers PGA, Elewaut D, Bos E, Verheijden GFM, et al. Human cartilage gp-39+, CD16+ monocytes in peripheral blood and synovium. Correlation with joint destruction in rheumatoid arthritis. Arthritis Rheum 2000;43:1233-43.

[40] Volck B, Johansen JS, Stoltenberg M, Garbarsch C, Price PA, Østergaard M, et al. Studies on YKL-40 in knee joints of patients with rheumatoid arthritis and osteoarthritis. Involvement of YKL-40 in the joint pathology. Osteoarthritis Cartilage 2001;9:203-14.

[41] Volck B, Price PA, Johansen JS, Sørensen O, Benfield TL, Nielsen $\mathrm{HJ}$, et al. YKL-40, a mammalian member of the chitinase family, is a matrix protein of specific granules in human neutrophils. Proc Assoc Am Phys 1998;110:35160.

[42] Johansen JS, Christoffersen P, Møller S, Price PA, Henriksen $\mathrm{JH}$, Garbarsch C, et al. Serum YKL-40 is increased in patients with hepatic fibrosis. J Hepatol 2000;32:91120.

[43] Harvey S, Weisman M, O’Dell J, Scott T, Krusemeier M, Visor J, et al. Chondrex: new marker of joint disease. Clin Chem 1998;44:509-16.

[44] Johansen JS, Stoltenberg $M$, Hansen M, Florescu A, Hørslev-Petersen K, Lorenzen I, et al. Serum YKL-40 concentrations in patients with rheumatoid arthritis: relation to disease activity. Rheumatology 1999;38:618-26.

[45] Nordenbaek C, Johansen JS, Junker P, Borregaard N, Sørensen O, Price PA. YKL-40, a matrix protein of specific granules in neutrophils, is elevated in serum of patients with community-acquired pneumonia requiring hospitalization. J Infect Dis 1999;180:1722-6.

[46] Kronborg G, Østergaard C, Weis N, Nielsen H, Obel N, Pedersen SS, et al. Serum level of YKL-40 is elevated in patients with Streptococcus pneumoniae bacteremia and is associated to the outcome of the disease. Scand J Infect Dis 2002;34:323-6.

[47] Tran A, Benzaken S, Saint-Paul M-C, Guzman-Granier E, Hastier P, Pradier C, et al. Chondrex (YKL-40), a potential new serum fibrosis marker in patients with alcoholic liver disease. Eur J Gastroenterol Hepatol 2000;12:989-93.

Available online at www.sciencedirect.com science $\boldsymbol{d}$ Directo 